
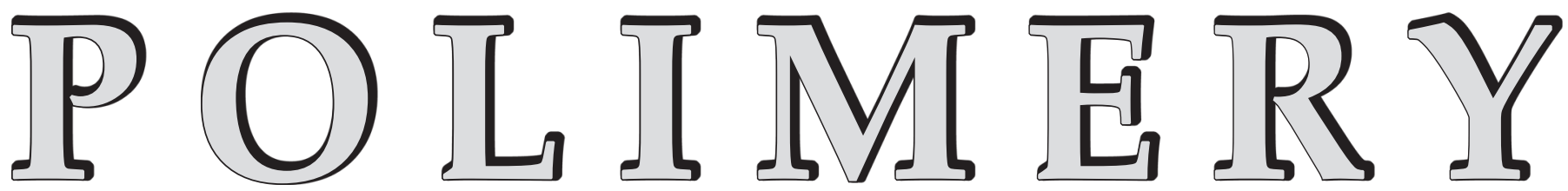

\title{
Nanocellulose from agricultural waste as an emerging nanotechnology material for nanotechnology applications - an overview
}

\author{
Nur Athirah Abdullah") (ORCID ID: 0000-0003-3569-6055), Mohd Saiful Asmal Rani ${ }^{1), 33, *)}$ (0000-0002-3909-1259), \\ Masita Mohammad ${ }^{1)}$ *) (0000-0002-5573-7048), Muhammad Hanif Sainorudin ${ }^{1)}$ (0000-0002-9177-5906), \\ Nilofar Asim ${ }^{1)}$ (0000-0002-4736-4958), Zahira Yaakob ${ }^{1)}$ (0000-0002-8259-1785), Halim Razali' ${ }^{1)}(0000-0003-4173-9891)$, \\ Zeynab Emdadi ${ }^{2)}(0000-0002-8085-5150)$
}

DOI: dx.doi.org/10.14314/polimery.2021.3.1

\begin{abstract}
It has been shown that in the last decades nanotechnology plays a key role not only in science but more and more often in industry as well. Recent research has shown that agricultural waste is a possible feedstock to produce nanocellulose which can be used for different applications, such as a biosensor, semiconductor and reinforcing agent. The use of agro-waste as a precursor not only offers advantages for raw material costs, but also for the climate, low processing costs, availability and convenience. It also helps to address environmental issues, such as illness, foul odor and concerns with indoor use. Different processes, such as chemical treatment, mechanical treatment and chemo-mechanical treatment, have been used to extract nanocellulose from agro-waste. This article highlights the latest technologies used to acquire agro-waste nanocellulose, as well as existing advances in and applications of nanocellulose technologies.
\end{abstract}

Keywords: nanocellulose, agricultural waste, biopolymer, nanotechnology, green products.

\section{Nanoceluloza z odpadów rolniczych jako nowy materiał materiał do zastosowań $w$ nanotechnologii - przegląd}

Streszczenie: $\mathrm{W}$ ostatnich dziesięcioleciach nanotechnologia odgrywa kluczową rolę nie tylko w nauce, ale coraz częściej także $w$ przemyśle. Wyniki prowadzonych badań wskazują, że odpady rolnicze mogą stanowić potencjalny surowiec do produkcji nanocelulozy. Wiadomo, że nanoceluloza jest doskonałym materiałem do różnych zastosowań, m.in. jako biosensor, półprzewodnik i czynnik wzmacniający włókna. Wykorzystanie agroodpadów jako surowca jest korzystne nie tylko ze względu na ich cenę, ale także ze względu na potencjalnie niewielki wpływ na klimat, niskie koszty i łatwość przetwarzania oraz dostępność. Niweluje również możliwe problemy wynikające z emisji nieprzyjemnych zapachów i ich negatywnego wpływu na zdrowie organizmów żywych. Do ekstrakcji nanocelulozy z agroodpadów stosuje się procesy obróbki chemicznej, obróbki mechanicznej i obróbki chemiczno-mechanicznej.

\footnotetext{
1) Universiti Kebangsaan Malaysia, Solar Energy Research Institute (SERI), 43600 Bangi, Selangor, Malaysia.

2) Iran University of Science and Technology, Department of Chemistry, Catalysts and Organic Synthesis Research Laboratory, Tehran 16846-13114, Iran.

3) National Defence University of Malaysia, Research Centre for Tropicalisation, Sungai Besi Camp, 57000 Kuala Lumpur, Malaysia.

*) Authors for correspondence: iker.asmal55@gmail.com, masita@ukm.edu.my
} 
Przedstawiono najnowsze technologie wykorzystywane do pozyskiwania nanocelulozy z agroodpadów, a także dotychczasowe postępy i zastosowania technologii z użyciem nanocelulozy.

Słowa kluczowe: nanoceluloza, odpady rolnicze, biopolimer, nanotechnologia, "zielone” produkty.

Agro-waste is an unusable substance that can be either a solid or a liquid formed as a by-product of food production processes, such as pesticides, crop residues and waste from livestock [1]. As a long-term strategy for the production of the enormous wealth of natural plant fibers currently in use, the use of natural fibers, especially agricultural waste fibers, requires further growth [2].

Several research on the potential of agricultural waste as an alternative fiber or material have been undertaken to obtain renewable and earth-friendly products. Environmental protection involves the recycling and reuse of waste products from natural resources, reducing usage and minimizing the use of non-degradable products. Furthermore, if handled properly, agro-wastes could produce good profits.

Some of the abundant agro-wastes containing cellulose or fibers are shown in Fig. 1, of which only $10 \%$ are used for manufacturing of valuable items, such as biocomposites, automotive components and biomedical components [2]. These agro-wastes, referred to as cellulose fibers (CFs), are an essential fiber source. With an estimated annual production of over 7.5 to 1010 tones, cellulose is the most abundant renewable organic material produced in the biosphere [3]. Cellulose is generally spread in higher plants, most aquatic species (e.g. tunicates), algae, fungi, bacteria, invertebrates and even ameba (e.g. Dictyostelium discoideum) to a lesser extent. In general, cellulose is a fibrous, strong, water-insoluble material that plays an important role in maintaining the structure of the walls of plant cells [3]. They have potential as reinforcement materials because, compared to hard woody materials, they are affordable, lightweight, sustainable, degradable, and soft. The lignocellulosic fiber, of which wood is the most important source, is the main source of cellulose in forests [4]. Other cellulose-containing products include crop residues, water plants, algae, grass and other plant substances. Not only do they contain cellulose, they also contain hemicellulose, lignin and a relatively limited number of extractives. Commercial cellulose production focuses on harvested sources such as wood or, of course, high pure sources such as cotton [4].

In order to reduce fossil fuel use, biomass is gaining popularity because it is a readily available source of renewable energy. These agro-wastes or biomass are generated from agricultural production on an ongoing basis and in large quantities. Some of these agricultural wastes are used to produce heat and electricity as a raw material for fuel [5]. Due to its poor fuel properties, such as high moisture and ash content, low bulk density, low energy content and storage, handling, and transport difficulties, the use of biomass for energy conversion is still considered to be minimal. Not only does the excess bio- a)

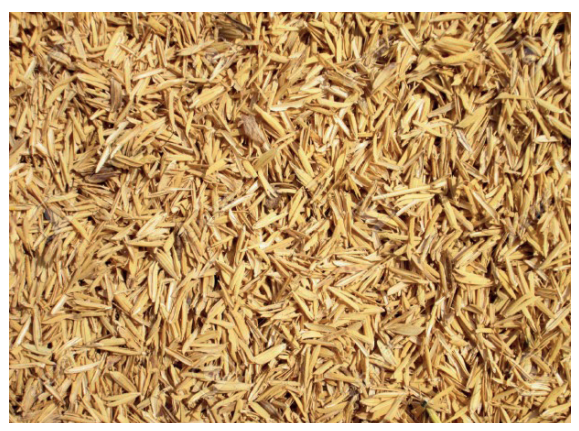

d)

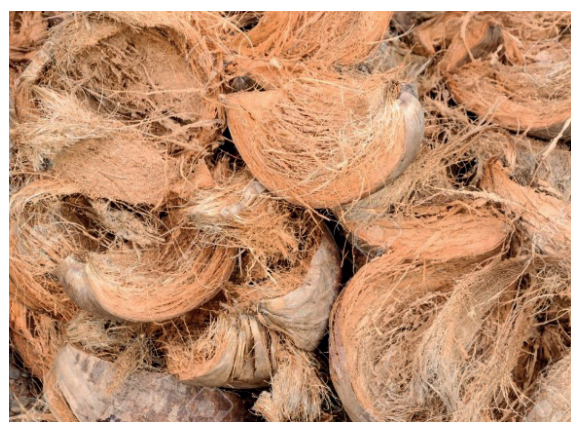

b)

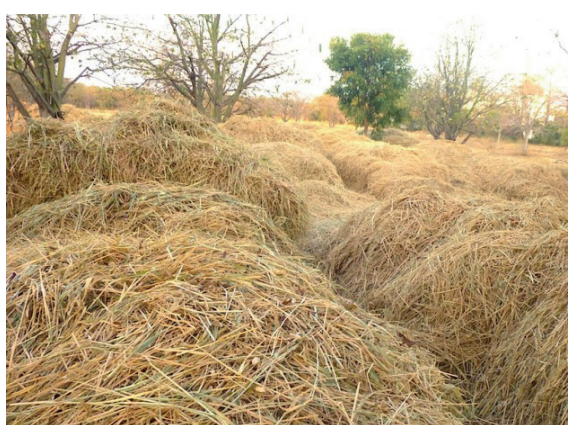

e)

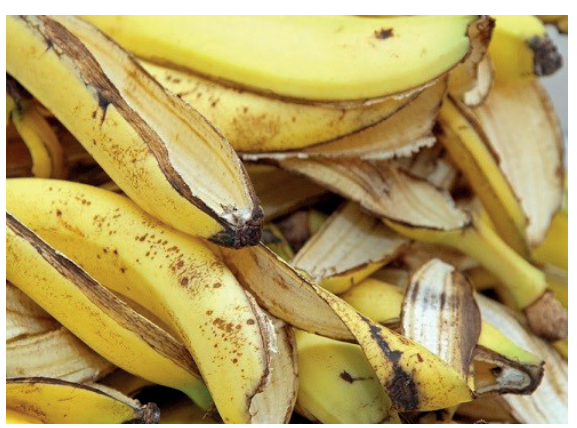

c)

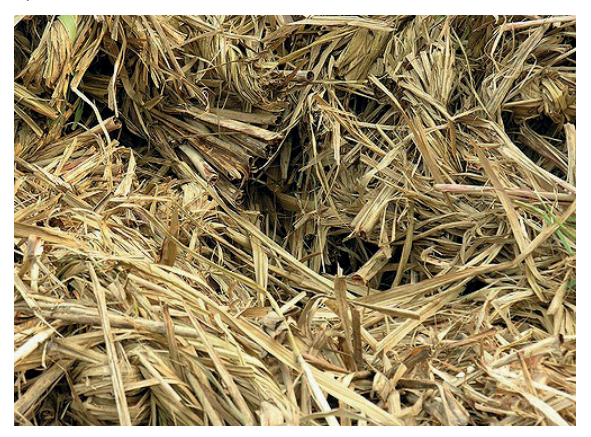

f)

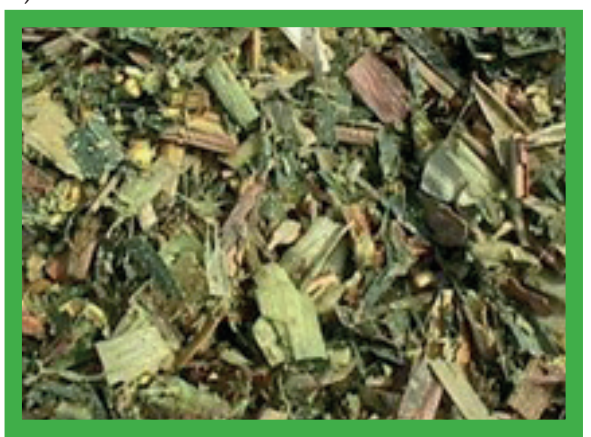

Fig. 1. Agricultural residues for energy sources: a) rice husk, b) rice straws, c) baggase, d) coconut coir, e) banana, g) pineapple leaf 
mass produced from agricultural industries cause problems with disposal, but it is also considered a waste of primary resources [5].

Numerous attempts have been made to develop suitable and cost-effective methods for the nanoscale degradation of cellulose fibers into their secondary components. Pretreatment, for example, requires the production of synthetic drugs to evacuate most of the waxes, extractives, hemicelluloses and lignin fiber. Next, the fibers are mechanically divided into smaller-scale/nanoscale fibrils by smashing, ultrasonic, steam explosion, high-pressure homogenization or a combination of those handling techniques [6]. Chemical improvements to traditional organic polymers are valuable techniques for discovering new materials with enhanced properties [7]. Acid hydrolysis, bleaching and alkali treatment are examples of chemical extraction.

For perspective applications, standard cellulose-based fibers are increasingly considered as building materials and support parts of engine vehicles where a decrease in weight and molecule size is significant. There are no less than 1000 plant types that are used to manufacture fibers that are industrially functional, that agro-wastes are a noticeable source of fibers based on cellulose. These include coir, straw build-up, bagasse, coffee husk and many more [8]. The contents of a nanometer-sized fiber improves many properties of terminal product, such as mechanical power, elevated surface energy, temperature of glass transition and improved surface reactivity. Packaging, filtration membranes, composites and textiles are the main markets for CNF. For the largest part of the current sales for CNFs, polymeric nanofibers account for applications in a range of industries [9]. Cellulose can have modern applications that contribute to marketing. Cellulose has an incredible potential in the nanosized regime and could benefit many industries due to its attractive properties, such as the beauty and pharmaceutical industries [10]. Applications in nanotechnology fields, such as biosensors, energy devices and biocomposites, may also be accessible. Instead of standard base materials such as glass fibers, carbon and powders, the use of cellulose fibers has many advantages, such as low thickness, low complexity, strong mechanical properties, low instrument wear and biodegradability. In various applications, such as in the biomedical field, in bioimaging and as a nanocomposite, gas barrier film and optically transparent material, cellulose nanofibrils (CNFs) have demonstrated incredible potential [11]. Energy storage has become a global issue in recent decades as a result of skyrocketing energy demands and an increasing awareness of the environmental implications of fossil fuel use. To solve these issues, a strong call for renewable energy sources has been launched worldwide [12]. The interests of cellulose scientists have changed with the advent of nanotechnology to extracting nanocellulose from various plant sources and using it in technological applications. Nanocelluloses also combine the important properties of cellulose with the remarkable characteristics of nanoscale materials [13].

This analysis paper highlights the issues surrounding agricultural waste nanocellulose, its role in recycling initiatives and advances in nanotechnology applications. Furthermore, the paper addresses the extraction method of nanocellulose and its application.

\section{AGRICULTURAL WASTE}

\section{Natural fibers}

Natural fibers are considered as a sustainable, environmentally friendly and useful resources because of their usefulness as an alternative to inorganic fillers and fibers. In the composite industry, they are usually referred to as plant fibers and are further categorized as wood or nonwood sources. Fiber sources are also called agro-waste, such as rice husks and rubber plant waste, corn, soybean, cocoa, sugar cane production, timber/wood and palm oil production [14, 15].

Wastes from rural and agricultural operations cause issues with waste management. Increased pollution problems arise from the agro-wastes generated each year. To minimize the environmental impact, the use of agro-waste is therefore significant. These biological wastes have tremendous potential as sustainable feedstocks for biofuels, biochemicals and biomaterials via biorefinery concepts [16]. Advanced research has been carried out worldwide to isolate beneficial compounds from agrowaste in order to make them a value-added commodity that can be commercialized on an industrial scale [3].

Provided their biological and organic properties, agro-wastes are a biomass. Biomass is a source of renewable energy that can either be used directly or converted into other energy products for energy production [5]. Biomass materials typically contain three main constituents: cellulose, lignin and hemicellulose. The most abundant renewable natural material produced in the biosphere is cellulose, which is typically contained in plants, a few aquatic creatures and, to a limited degree, in green organisms such as algae, diatoms and cyanobacteria, microorganisms, spineless creatures and even amoebas [15, 17].

Cellulose is the most common polymer on Earth. In general, cellulose and other non-cellulosic materials act as the building blocks for natural fibers. It is possible to remove the cellulose that forms the primary constituent in natural fibers naturally. Hemicellulose, lignin and pectin are primarily the non-cellulosic components found in natural fibers [18]. Thus, for many purposes, it can be considered to be a very significant raw material. Recently, cellulose has gained considerable interest in the industry because of its possible use in the development of biofuels. In the cardboard products and paper market, it has been commonly used as a raw material. Moreover, in various applications, cellulose has shown value. It can be chemically modified to yield derivatives of cellulose. 


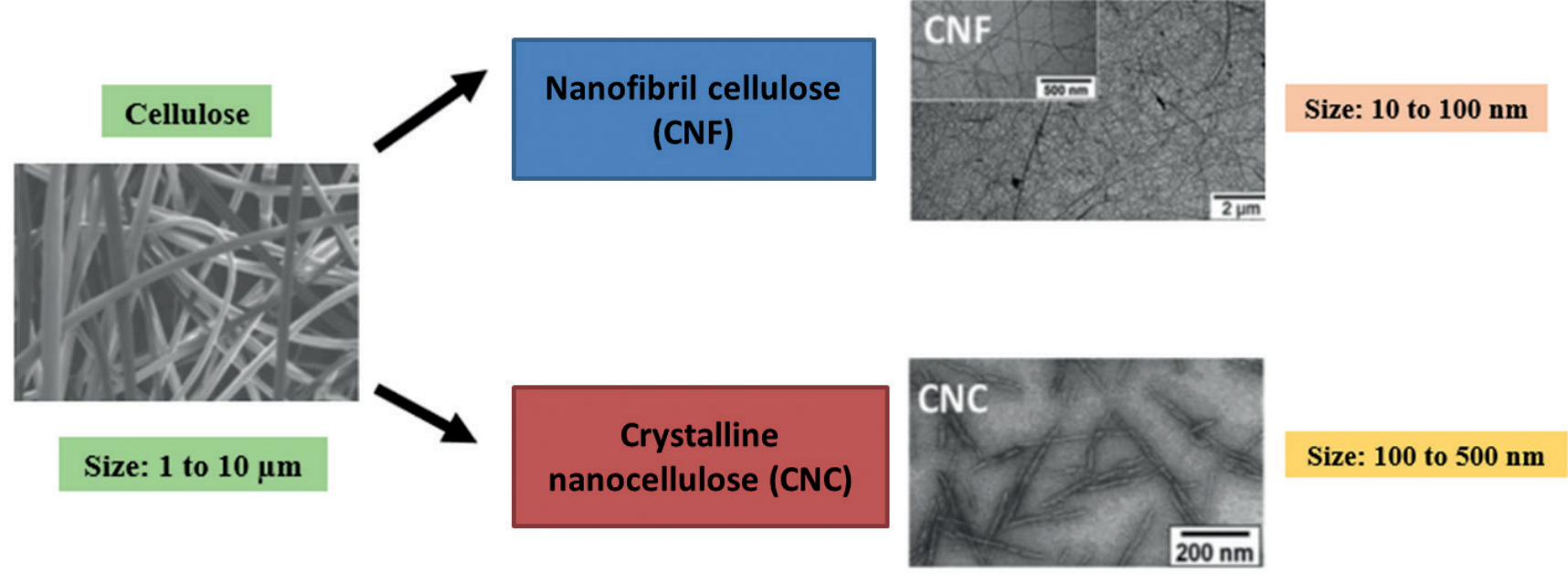

Fig. 2. Classification of nanocellulose extracted from agriculture waste

Cellulose is commonly used in different manufacturing industries, in addition to being used as a source for commodity products. However, the efficient use of cellulose as a material source has been challenging because of its poor solubility, especially in the chemical industry [19].

Cellulosic nanomaterials or nanocellulose are regularly referred to as the various kinds of nanomaterials that can be extracted from cellulose (Fig. 2). This type of cellulose can be identified as CNF and CNC that can be extracted from plants, micro-organisms and a few animals, such as tunicates. For a variety of applications, the extraction of cellulose may stimulate extensive research related to the processing of nanomaterials. Cellulose application strategies can include the use of CNFs as reinforcement materials in composites due to their high quality characteristics, efficiency and convenience, or the use of CNCs because of their high quality, renewability, light weight, high surface area and oxygen transmission rate capability [20]. As an alternative to micro-sized reinforcement materials in composite plastics, cellulose nanofiber (CNF) from sustainable biomass has attracted great interest. It can be used to improve the mechanical strength of general purpose thermoplastics, such as polypropylene (PP), polyethylene (PE), poly(vinyl chloride), poly(lactic acid) and nylon, because of its strong rigidity [21].

\section{Cellulose and nanocellulose from agricultural waste}

\section{Current status on cellulose and nanostructure cellulose}

Raw materials such as coconut, palm oil, bagasse and pineapple are technically and economically feasible for the production of waste biomass from the agricultural sector. They may play a significant additional role in the form of fibers. The manufacture of composites, paper and engineered materials from agricultural waste materials has been defined as necessary. Tropical regions are widely known as areas rich in biomass fiber resource and diversity in abundance. For example, palm oils are biomass fiber assets that can largely be found in countries such as Malaysia and Indonesia in Asia. These two countries are the main producers of the agricultural industry in the world [2].

Extensive cellulose research has been performed in review articles and books describing the various sections of cellulose, i.e. particles and composites based on cellulose, including cellulose nitrate $(\mathrm{CN})$ cellulose regeneration, cellulose suspension rheological behavior, bacterial cellulose, CN composites, cellulose structures, cellulose surface chemical alteration, suspension self-assembly [22]. Due to the limited quantities of fossil fuels, their growing costs and the lack of biodegradability of petroleum-based polymers, renewable waste materials are increasing in value. Approximately $10 \%$ of its rough material requirements are considered to be fulfilled by the chemical industry from recycled waste materials [23].

In addition to cellulose, hemicelluloses, lignin and a comparatively limited number of extractives are also present in agro-wastes. Derivatives of some essential polymers, like thermoplastics, can be used as petrochemical replacements and different polymer-like reactions can be used to change cellulose [24]. Two decades ago, research into cellulose nanofiber as a reinforcement in nanocomposites began. Therefore, a lot of research has been based on cellulose nanofibers and it is an important topic to address [4]. Whether for system applications on a small scale or for structural materials on a larger scale, a deeper understanding of cellulose itself, which includes nanoscale structures, can open up new areas for use.

\section{Synthesis of cellulose and nanostructure cellulose}

Scientists and researchers use specific cellulose extraction techniques such as alkaline/acid treatment and chlorine-free extraction from various plant materials and plant waste, including wheat straw, soy frame, rice husk, 


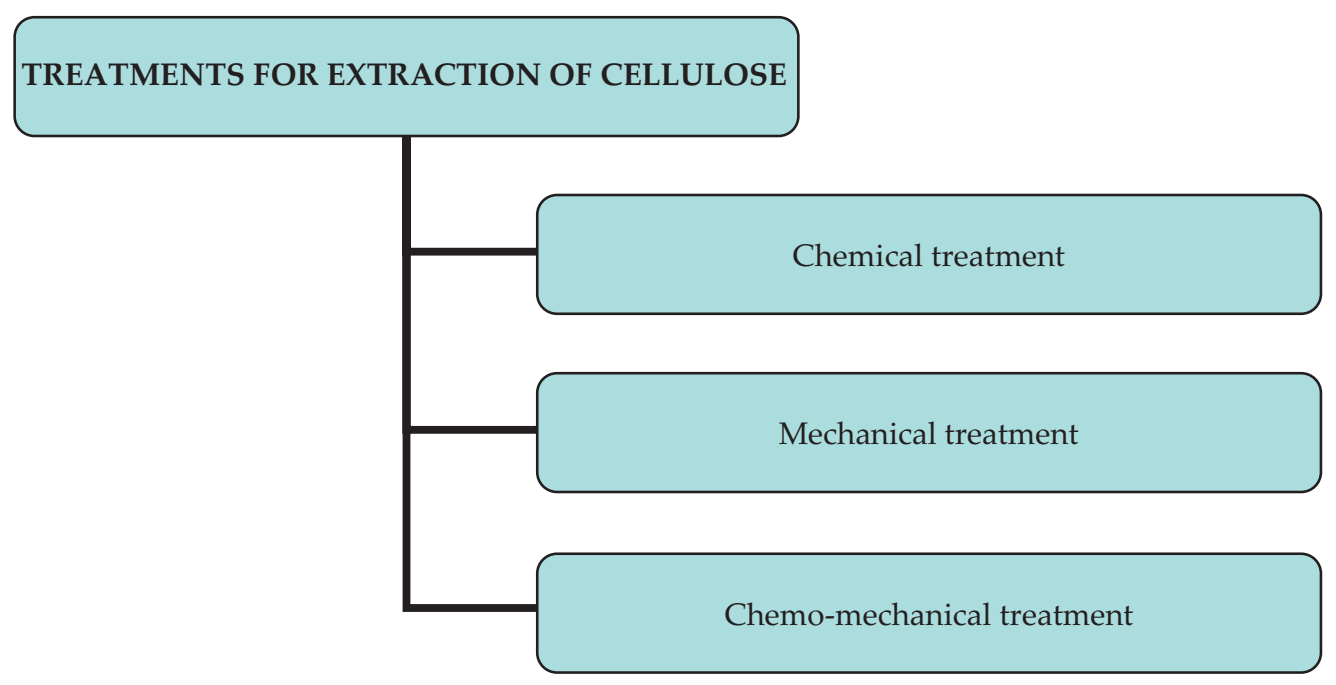

Fig. 3. Treatment procedures of extraction cellulose

and empty palm oil fruit [25]. In plant waste, cellulose fibers are made of various materials, including lignin, hemicellulose and pectin, and can be referred to as composites. According to the growth and shape of the plant, these materials are different. The separation of cellulose fiber from agricultural waste requires significant care along these lines. For the extraction of fibers from cellulose, there are various methods, such as chemical treatment, mechanical treatment and chemo-mechanical treatment (Fig. 3). Use of chemicals such as potassium hydroxide and sodium hydroxide are common methods for the extraction of cellulose. Too much use of chemicals can lead to environmental problems, especially when waste chemicals are improperly disposed of. The use of environmentally friendly pretreatment techniques, such as the use of superheated steam (SHS), hot compressed water and explosion of steam, has been confirmed [26]. The proportion of acid to fiber and treatment time effectively influences the cellulosic fiber separation and properties [2].

\section{Chemical treatment}

Chemical treatment has been commonly used in normal fibers to extract non-cellulosic materials, but it can weaken the crystalline structure. Numerous analysts have focused on the extraction by chemical treatment of cellulose from rural waste fiber using chlorite bleaching, alkali treatment and acid hydrolysis. Studies performed by Anuj Kumar (2014) [27], Roni et al. (2013) [28] and Jabbar (2016) [29] on sulfuric acid hydrolysis $\left(\mathrm{H}_{2} \mathrm{SO}_{4}\right)$ has been utilized on agricultural waste cellulose strands. A white-hued and artificially refined cellulose was produced by the chemical purification process by acidic sodium chlorite and alkali treatment, which was further hydrolyzed by acid to extract the CNCs. Characterization of nanocellulose fibers obtained from chemical treatment was carried out for the extraction of nanocellulose fibers from cellulose plant fibers, including sulfuric acid $\left(\mathrm{H}_{2} \mathrm{SO}_{4}\right)$. In another review by Lani et al. (2014) [30], they used sodium chlorite $\left(\mathrm{NaClO}_{2}\right)$ acid hydrolysis treatment on cellulose filaments from an empty bunch of fruit (EFB) and palm oil. Via acidic sodium chlorite and alkali treatment, the chemical purification process has been effective in expelling sections of lignin and hemicellulose. From an attempt by Piyaporn (2015) [31], an alkali treatment and a bleaching process for the preparation of cellulose nanocrystals from maize husks using acid hydrolysis resulted in cellulose nanocrystals having the most significant crystallinity index $(68.33 \%)$ and displaying the highest and sharpest peak at $2 \theta=22^{\circ}$. In comparison to the untreated maize husk, the increased crystallinity of the treated corn husk was attributed to the complex evacuation of unidentified non-cellulosic materials. Moreover, an improvement in the composition of cellulose and nanocellulose may be accomplished by the chemical treatment used as a part of this analysis.

\section{Mechanical treatment}

In order to isolate fiber cellulosic materials a few mechanical techniques, such as homogenization, ultrasonics and electrospinning, have been used. Refining, cryocrushing, crushing and microfluidization may also be viewed as other mechanical methodologies in addition to the disengagement process of fiber cellulose by homogenization. The use of electrospinning, which is a technique involving the application of external electric force to a polymer solution, is popular in MFC (Microfibrillated Cellulose) processing. As the surface tension of the polymer solution is resolved by electrostatic charge repulsion within the solution, a polymer solution jet is expelled at very high strain rates towards the MFC collector [26]. Mohamad (2012) [32] reviewed nanocellulose fibers from various sources (flax, banana tree and grass) utilizing a high-pressure microfluidizer. Another review by Zhang 


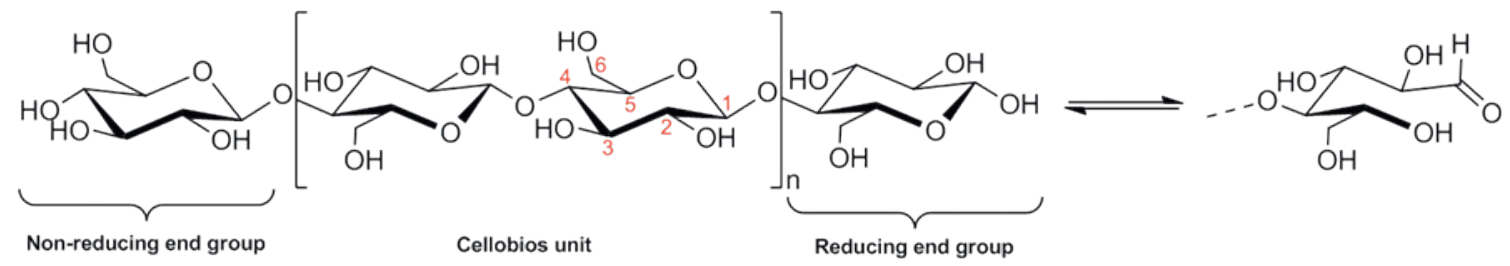

Scheme A. Direct homo-polysaccharide cellulose polymer consisting of D-anhydro glucopyranose units (AGU) connected by $\beta$-1,4-glycosidic bonds [25]

et al. (2016) [33] showed a technique for extracting cellulose from kenaf fibers extracted by steam explosion with different pressures and mechanical treatment was used. After the steam explosion procedure, the amount of hemicellulose and cellulose was calculated. In this study, the extreme load (3 MPa and greater) annihilated the cellulose structure, verified by changes in the spectrum of Fourier-transform infrared spectroscopy (FT-IR) and the index of crystallinity. Chen (2011) [34] used a mechanical treatment by ultrasonication to remove lignin from poplar wood. Using a pretreatment and high intensity ultra-sonication, cellulose nanofibers were isolated from poplar wood.

\section{Chemo-mechanical treatment}

To extract cellulose filaments from various lignocellulosic plants, chemo-mechanical procedures with a combination of chemical and mechanical treatments have been used recently. Saelee et al. (2014) [35] utilized steam explosion as the extraction technique for cellulose from sugarcane bagasse. By using steam explosion and a xylanase pretreatment and bleaching process, cellulose was separated from sugarcane bagasse. The chemical analysis revealed that the cellulose extracted had a greater content of cellulose and a lower content of hemicellulose and lignin than the crude material. In addition, the treatment with xylanase was effective in reducing compound fading by $23 \%$. In this way, steam explosion and xylanase pretreatment can be used for cellulose extraction from sugarcane bagasse. In addition, experiments have been carried out on crude strands such as banana, pineapple leaf fiber, jute and coir filaments using steam explosion combined with compound therapy [36]. In this study steam explosion combined with acid hydrolysis was found to be effective in acquiring strands from different plant fibers in the nanoscale range. Another review [37] was also focused on the extraction of nanocrystalline cellulose from sugar palm bunches using a chemo-mechanical treatment to isolate nanocellulose.

\section{Morphology of cellulose and nanocellulose from agriculture waste}

The structure of cellulose among the polysaccharides is special and fundamental. From their natural start, cellulose strands exhibit a fundamental progression. They are made of nanofiber collections with a diameter ran- ging from 2 to $20 \mathrm{~nm}$ and a length greater than a few micrometres [4]. In different sectors, cellulose is used in many applications. Purkait and colleagues initially discovered its effectiveness as a typical component in plant cell dividers [38]. Cellulose is highly polished and insoluble in natural solvents, making it the ideal basis for construction materials [24]. The cellulose polymer is a direct homo-polysaccharide consisting of $\beta-1,4$-glycosidic bonds bound together by $\mathrm{D}$-anhydroglucopyranose units (AGU). In relation to its neighbour, each and every other AGU is turned $180^{\circ}$ and two AGUs form a cellobiosis unit next to each other, the smallest repeating unit in the polymer (Scheme A) [25]. Cellulose can also be used by solid acid hydrolysis as a starting material for nanocellulose formation. This method supplied the local cellulose with negative charges from the acidic substances and hydrolyzed the uncertain section into nanosized fibers [39].

Cellulose is a distinctive polymer, polysaccharide consisting of a linear chain of several hundred to many thousands of $\beta(1 \rightarrow 4)$ linked D-glucose units. When water is extracted by combining the $\mathrm{H}$ and- $\mathrm{OH}$ aggregates, the sugar units are linked. A disaccharide called cellobioses is formed by connecting only two of these units. The glucose units are in 6-membered rings called pyranoses in the cellulose chain. They are joined between the C-1 of one pyranose ring and the C- 4 of the following ring by single oxygen atom (acetal linkages). The glucose units in the cellulose polymer are referred to as anhydroglucose units because an molecule of water is lost due to the reaction of acid and a hemiacetal to form an acetal [40].

Cellulose has a non-resistant against itself and substances containing hydroxyl. Cellulose is particularly receptive to water considering the dominance of hydroxyl functional groups. Cellulose can have a minimum number of monomolecular layers and up to a few molecular layers of water attached to it under simple conditions. In an array of solvents, cellulose is highly stable and must be broken up with the use of solid acids or solid hydrogen-holding dissolvable frameworks, often amine-based. The thermal properties of cellulose are that the temperature shift of the cellulose crystal is in the range of 200 to $230^{\circ} \mathrm{C}$, which is near its warm degradation temperature of $260^{\circ} \mathrm{C}$ [41].

The isolation, classification and quest for applications of novel cellulose forms, referred to as whiskers (CNW), CNC and CNF, is currently of significant interest [40]. 
All nanocellulose materials combine high-quality cellulose with a high surface area, making them promising as composite bio-based materials [42]. The nanocellulose family has three forms of cellulose: microfibrillated cellulose (MFC), nanocrystalline cellulose (NCC) and bacterial nanocellulose (BNCC) [40]. Gel-like features are expressed in microfibrillated cellulose. Likewise, it has a high ratio of surface to volume. This means that the surface plays a primary function not only in the mechanical efficiency of stress transfer in a nanocomposite, but also in the ability to modify scientific research [4]. A second form of nanocellulose, namely nanocrystalline cellulose, was formed by the elimination of amorphous parts of partially crystalline cellulose by acid hydrolysis. The liquid-crystalline properties of NCC suspensions are described in [40].

BNCs are a pure portion of biofilms, such as acetic acid bacteria of the genus Gluconacetobacter, also known as biocellulose, microbial cellulose or bacterial cellulose (BC). Such forms of cellulose are common in nature, where sugars and plant carbohydrates are fermented. BNC differs from MFC and NCC because biotechnological assembly processes from low-molecular weight carbon sources such as D-glucose are produced as a polymer and nanomaterial, whereas MFC and NCC materials are isolated from cellulose sources [40]. Bacterial cellulose (BC) has a high flexibility and hydrophilic porous structure and is a low-cost biopolymer. These specific characteristics allow researchers to use BC for the development of electrodes for fuel cells, batteries, and supercapacitors. Many nano-scale carbons such as CNTs and graphene and even conductive polymers such as polyaniline (PANI) and polypyrrole have shown simple binder-less coating of BC [43].

Cellulosic nanomaterials or nanocellulose are also the types of nanomaterials that can be delivered from cellulose. For example, the extraction from plants, microorganisms and a few animals (e.g., tunicates) of CNF and $\mathrm{CNC}$ encourages to research into the applications of these nanomaterials [22]. Because of their high-qual-

T a b l e 1. Chemical composition from different agricultural wastes

\begin{tabular}{|c|c|c|c|c|c|c|}
\hline & $\begin{array}{c}\text { Cellulose } \\
\text { wt } \%\end{array}$ & $\begin{array}{c}\text { Hemicellulose } \\
\text { wt \% }\end{array}$ & $\begin{array}{l}\text { Lignin } \\
\text { wt \% }\end{array}$ & $\begin{array}{c}\text { Moisture } \\
\text { content, wt \% }\end{array}$ & Nanocellulose & References \\
\hline \multicolumn{7}{|c|}{ RAW WASTE } \\
\hline Banana fiber & 69.9 & 19.6 & 5.7 & 9.8 & N/A & \\
\hline Coir fiber & 39.3 & 2 & 49.2 & 9.8 & N/A & [36] \\
\hline Jute fiber & 68.3 & 15.4 & 10.7 & 10.1 & N/A & \\
\hline Pineapple leaf fiber (PALF) & 81.27 & 12.31 & 3.46 & 10.52 & N/A & [45] \\
\hline Sugarcane bagasse & 44.5 & 21.8 & 22.5 & N/A & 76.0 & {$[29,46]$} \\
\hline Pineapple leaf & 66.2 & 19.5 & 4.28 & N/A & N/A & \\
\hline Corn stalk & 39.0 & 42.0 & 7.30 & N/A & N/A & [47] \\
\hline Napier grass & 12.4 & 68.2 & 10.8 & N/A & N/A & \\
\hline Kenaf & 63.5 & 17.6 & 12.7 & N/A & 82.6 & [48] \\
\hline Corn husk & 29.3 & 39.7 & 11.4 & N/A & 68.33 & [31] \\
\hline Oil palm frond & 39.13 & 23.04 & 34.37 & N/A & N/A & [49] \\
\hline Cocoa pod husk & 35.4 & 37.0 & 14.7 & N/A & N/A & [50] \\
\hline \multicolumn{7}{|c|}{ BLEACHING } \\
\hline Banana fiber & 96.8 & 0.2 & N/A & 9.3 & N/A & \\
\hline Coir fiber & 97.3 & 0.2 & 0.2 & 8.9 & N/A & [36] \\
\hline Jute fiber & 97.3 & N/A & 0.3 & 9.6 & N/A & \\
\hline PALF & 88.0 & N/A & N/A & 8.5 & N/A & [41] \\
\hline Sugarcane bagasse & 89.3 & 4.3 & 1.5 & N/A & N/A & {$[29,46]$} \\
\hline Kenaf & 92.8 & 4.7 & 0.5 & N/A & N/A & [48] \\
\hline Pineapple leaf & 98.63 & 0.53 & 0.77 & 10.80 & 92.8 & [47] \\
\hline Corn husk & 97.6 & 1.9 & 0.2 & N/A & N/A & [31] \\
\hline \multicolumn{7}{|c|}{ STEAM EXPLOSION } \\
\hline Banana fiber & 88.3 & 6.9 & 2.9 & 10.1 & N/A & \\
\hline Coir fiber & 57.4 & N/A & 30.9 & 8.8 & N/A & [36] \\
\hline Jute fiber & 86.7 & 4.3 & 3.5 & 10.4 & N/A & \\
\hline PALF & 93.45 & 3.72 & 2.08 & 10.64 & N/A & [45] \\
\hline Sugarcane bagasse & 65.7 & 9.9 & 18.3 & N/A & N/A & {$[29,46]$} \\
\hline Kenaf & 55.32 & 11.86 & N/A & N/A & N/A & [33] \\
\hline
\end{tabular}


ity properties, relative minimal effort and usability, diagrams include using CNFs as reinforcing components in composites. CNCs have the advantages of high quality, renewability, light weight, high surface area and photonic characteristics of one kind [44].

\section{Chemical composition of cellulose and nanocellulose from agricultural waste}

Cellulose is a naturally occurring biopolymer in plant cells, such as wood and cotton. It is the principal constituent of trees and plants in the cell wall, and the most abundant polymer in nature. In cotton, which is approximately $90 \%$ cellulose, the highest cellulose content is found compared to bast fibers, such as flax, hemp or ramie, which have approximately $70-80 \%$ cellulose content, and wood, which has about $40-50 \%$ cellulose content. In addition to wood and plants, which consist of proteins and carbohydrates, cellulose may also be contained in different bacterial organisms, tunicates, algae and sea animals [25]. Another example of fibers that contain cellulose can be found in Table 1.

\section{APPLICATION OF CELLULOSE AND NANOCELLULOSE AS A NATURAL BIOPOLYMER}

For the next wave of superior biocomposites, nanocellulose is often used as a cutting-edge sustainable reinforcement. Natural fibers are also regarded as ideal reinforcements for green composites because of their low cost, low density, renewability and biodegradability. However, natural fibers as reinforcements can cause many pro- blems compared to synthetic fibers such as glass, aramid or carbon fibers, such as high linear coefficients of thermal expansion, susceptibility to moisture, limited processing temperature, poor absolute tensile strength and inconsistency of batch-to-batch [51]. Pre-treatments of cellulose fibers can modify the surface of the fiber; for example, surface alteration prevents the absorption of moisture and increases the surface roughness [52].

In other words, the high stiffness of the cellulose crystal for reinforcement will theoretically leverage the cellulose nanofibers in composite materials. The plant hierarchical structure will break down into high crystallinity individualized nanofibers, thus reducing the amount of present amorphous material (Table 2) [53].

The consideration, research and production of common fiber, biopolymers and polymer materials for their use in biocomposites, packaging, agriculture, medicine and so on has increased significantly. In order to obtain user-friendly polymer composites and advanced materials, numerous researchers have customized fiber and polymer features [74]. In aqueous media, polymers are usually mixed with NCC by simple mixing at room temperature and, at times, under vacuum to preserve the incidence of air bubbles in the last film. Films may be framed by film throwing from these blends, where the solvent is vaporized at direct temperatures, or by conventional methods, such as hot pressing and expulsion (usually followed by solvent molding or freezing). Without damaging it, the sort of holder used for throwing should be prepared carefully. Popular holders are made of teflon, PP or glass. Thermal, chemical or photo-cross-linking agents may be used to make NCC or any other polymer theoretically tougher [74].

$\mathrm{T}$ a b 1 e 2. Sources of raw nanocellulose and extraction process

\begin{tabular}{|c|c|c|c|}
\hline Name & Source & Process & References \\
\hline \multirow{4}{*}{ CNW } & Ramie & \multirow{4}{*}{$\mathrm{H}_{2} \mathrm{SO}_{4}$ hydrolysis } & [54] \\
\hline & MCC & & [55] \\
\hline & MCC & & [56] \\
\hline & MCC & & [57] \\
\hline CNW & Cotton linters & $\mathrm{HCl}$ hydrolysis & [58] \\
\hline Whiskers & Cellulose fibers & $\mathrm{H}_{2} \mathrm{SO}_{4}$ hydrolysis & {$[59,60]$} \\
\hline NF & Wheat straw & $\mathrm{HCl}+$ mechanical treatment & [61] \\
\hline $\mathrm{NCC}$ & $\mathrm{MCC}$ & $\mathrm{H}_{2} \mathrm{SO}_{4}$ hydrolysis & [62] \\
\hline MCC & Alpha-cellulose fibers & Hydrolysis & [63] \\
\hline Cellulose crystallites & Cotton Whatman filter paper & HSO bud nolucis & [64] \\
\hline Nanocellulose & Sisal fibers & $\mathrm{H}_{2} \mathrm{SO}_{4}$ hydrolysis & [65] \\
\hline MCC & Cotton Whatman filter paper & $\mathrm{HCl}$ hydrolysis & [66] \\
\hline NF & Soybean pods & Chemical treatment + high pressure defibrillator & [67] \\
\hline \multirow{5}{*}{$\mathrm{CNC}$} & Cotton Whatman filter paper & \multirow{4}{*}{$\mathrm{H}_{2} \mathrm{SO}_{4}$ hydrolysis } & {$[68,69]$} \\
\hline & Bacterial cellulose & & [70] \\
\hline & Cotton (cotton wool) & & [71] \\
\hline & MCC & & [72] \\
\hline & MCC & Sonication & [73] \\
\hline
\end{tabular}


A multiphase material where the polymer is reinforced with a nanomaterial is a polymer nanocomposite. Due to their nanometric scale and the extended surface zone of the reinforcing material, these polymer nanocomposites exhibit interesting properties. In a large number of applications, CNW, NCC and CNC are very promising building blocks for sustainable materials. In addition to their mechanical properties, such as very high strength, CNCs at sufficient concentration can form a so-called chiral nematic phase, although the chirality transfer mechanism from the molecular scale to the colloidal scale has not yet been completely resolved [75]. In various polymer nanocomposite frameworks, CNCs are used as heap-bearing constituents because they can produce important improvements in mechanical properties even at low volumes. Moreover, its high degree of perspective, great dispersion of hydrophilic principles and the ability to disperse through a polymer framework make it a commonly chosen reinforcement material [42]. As a polymer nanocomposite, CNCs are often used to confer adequate efficiency and modulus as model nanofillers with a characterized morphology. For the development of nanocomposites, both natural and processed polymers are used. For nanocomposites, a few standard polymers are used, such as starch, chitosan, natural elastic, butyrate derived from cellulose acetic acid, carboxymethyl cellulose, hydroxypropyl methylcellulose, gelatin and soy protein [76]. Some of the polymers produced are also used, such as poly(vinyl alcohol) (PVA), poly(vinyl chloride), polyethylene, polycaprolactone, polypropylene and polyurethane [42]. The most significant and commonly used polyolefin is PP. Its low density, low cost of production, versatility of design and recyclability make it a common option for composite making as a matrix. PP is hydrophobic, which results in compatibility problems when polar surface fillers such as cellulose are used [21].

\section{FUTURE PROSPECTS}

Cellulose is known as a natural polymer that is biodegradable and reusable. Biocompatibility, biodegradability and renewability are at its disposal. There are also other benefits of cellulose, such as high porosity, large specific surface area and low density (Table 3) [77].

In many fields, it can be used in the areas of thermal insulation, biomedical applications, adsorption and oil/water separation for many purposes [78]. Cellulose is a well-known non-toxic and low-cost polymer. It is also a polymer that is naturally biocompatible and it has been used in many fields. Due to the high potential of industrial applications, including batteries, sensors and electrical equipment, the manufacture of polymer-cellulose composites has attracted considerable attention in recent years [79]. Nanocellulose has also attracted attention for its use as a medicinal material due to its surface chemistry, physical properties and excellent biological properties (biodegradability, low toxicity and biocompatibility) because of its special and promising natural material derived from native cellulose. Bacterial cellulose (BC), cellulose nanocrystals (CNC) and cellulose nanofibrils (CNF) were three different forms of nanocellulose that were introduced and compared in terms of production, properties and biomedical applications [80].

$\mathrm{T}$ a b l e 3. Characteristics and properties of the major constituents in lignocellulose fibers [77]

\begin{tabular}{|c|c|c|c|}
\hline $\begin{array}{l}\text { Lignocellulosic } \\
\text { material/characteristic }\end{array}$ & Lignin & Hemicellulose & Cellulose \\
\hline Shape and physical structure & Random, amorphous structure & Random, amorphous structure & $\begin{array}{c}\text { Slender rod like crystalline } \\
\text { microfibrils made of solid } \\
\text { cellulose } \\
\text { High order: crystalline } \\
\text { Low order: amorphous }\end{array}$ \\
\hline Chemical structure & $\begin{array}{l}\text { Complex hydrocarbon } \\
\text { polymer with both aliphatic } \\
\text { and aromatic constituents. } \\
\text { Contains five hydroxyl and } \\
\text { five methoxy groups per } \\
\text { building unit }\end{array}$ & $\begin{array}{l}\text { A group of polysaccharide- } \\
\text {-rides composed of a of both } \\
5 \text { - and 6-carbon ring sugars }\end{array}$ & $\begin{array}{l}\text { D-anhydro glucose }\left(\mathrm{C}_{6} \mathrm{H}_{11} \mathrm{O}_{5}\right) \\
\text { repeating units joined by } \\
1,4-\beta-\mathrm{D} \text {-glycosidic linkages } \\
\text { at } \mathrm{C} 1 \text { and } \mathrm{C} 4 \text { position. Each } \\
\text { repeating unit contains three } \\
\text { hydroxyl groups }\end{array}$ \\
\hline Degree of polymerization & NA & $50-300$ & 10000 \\
\hline Hydrophobicity & Hydrophobic & Very hydrophilic & Hydrophilic \\
\hline Thermoset/thermoplastic & Thermoplastic & Thermoplastic & Thermoset \\
\hline Melting temperature & $170^{\circ} \mathrm{C}$ & $\mathrm{N} / \mathrm{A}$ & $\mathrm{N} / \mathrm{A}$ \\
\hline Glass transition temperature & $90^{\circ} \mathrm{C}$ & $\mathrm{N} / \mathrm{A}$ & $\mathrm{N} / \mathrm{A}$ \\
\hline Solubility in alkali & Soluble in hot alkali & Soluble in alkali & $\begin{array}{l}\text { Resistant to strong alkali } \\
\qquad(17.5 \mathrm{wt} \%)\end{array}$ \\
\hline Solubility in acid & Not hydrolysed in acid & Easily hydrolysed in acids & $\begin{array}{c}\text { Easily hydrolysed by acid to } \\
\text { water-soluble sugars }\end{array}$ \\
\hline Oxidizing agent resistance & Not resistant & Not resistant & Resistant \\
\hline
\end{tabular}


As a result of studies on the chemical and physical properties of cellulose and nanocellulose, numerous advances have been made with respect to environmentally friendly usable cellulose-based materials, such as cellulose films, cellulose fibers, cellulose aerogels, cellulose hydrogels and cellulose-based composites [81]. The exploration of energy storage technologies, especially large-scale battery storage technologies is important and could be a solution to these global concerns [12]. However, there are still problems with the preparation and alteration of cellulose. Firstly, during the drying process, nanocellulose is vulnerable to self-agglomeration, and the cost of nanocellulose and bacterial cellulose is high. In addition, the process of solvent exchange appears to be very time-consuming; it is therefore difficult to recover cellulose solvents during regenerated cellulose preparation. Second, some cellulose modification methods are relatively costly and complex, and cellulose is still unable to meet the requirements of many actual applications based on its structural strength and stability efficiency (such as thermal stability and repeated adsorption capacity).

Therefore the following problems should be addressed for future research and cellulose growth. The dissolution efficiency of cellulose needs to be improved and cheap, reliable, non-toxic cellulose and environmentally friendly solvent systems must be developed. Furthermore, the processes of solvent exchange must be progressed to shorten the production cycle. Safe methods of drying and quick and low-cost facilities should be explored. Finally, to assess the potential for cellulose efficiency and stability, physical mixing or chemical modifications should be enhanced.

\section{CONCLUSIONS}

The plan to transform agro-wastes into products has been in progress for some time. However, there are also some disadvantages, such as limited technology related to the use agro-waste product. In the coming decades, proposals for future green, economical and renewable energy should involve the increased use of agricultural waste. As possible strengthening materials for various applications, cellulose fibers from agro-wastes are being used. Cellulose fibers can be used in many applications, such as for the production of vehicles, furniture, appliances, drugs and beauty products. These materials are waste from biomass and exhibit great mechanical properties. The increased use of rural waste for bio-composite agro-based products depends on the growing effect of the agriculture sector.

\section{ACKNOWLEDGMENTS}

The authors received funding support MI-2019-018 and FRGS/1/2019/TK10/UKM/02/1 from CRIM (Centre for Research and Instrument Management, UKM and MoHE (Ministry of Higher Education), Malaysia.

\section{REFERENCES}

[1] Nitu Sindhu, Shehrawat P.S., Bharat Singh: Annals of Agri Bio Research 2015, 20, 110.

[2] Dungani R., Karina M., Sulaeman A. et al.: Asian Journal of Plant Sciences 2016, 15 (1/2), 42. http://dx.doi.org/10.3923/ajps.2016.42.55

[3] Habibi Y., Lucia L.A., Rojas O.J.: Chemical Reviews 2010, 110 (6), 3479. https://doi.org/10.1021/cr900339w

[4] Rani M.S.A., Rudhziah S., Ahmad A., Mohamed N.S.: Polymers 2014, 6 (9), 2371. https://doi.org/10.3390/polym6092371

[5] Ani F.N.: "Utilization of bioresources as fuels and energy generation" in: "Electric Renewable Energy Systems", Elsevier Inc., pp. 140-155. ISBN 978-012804448-3.

[6] Xu C., Zhu S., Xing C. et al.: PLoS One 2015, 10 (4), e0122123.

https://doi.org/10.1371/journal.pone.0122123

[7] Phiriyawirut M., Maniaw P. Open Journal of Polymer Chemistry 2012, 2 (2), 56.

http://dx.doi.org/10.4236/ojpchem.2012.22007

[8] Khan G.M., Alam M.: Indian Journal of Fiber \&Textile Research 2012, 37, 20.

[9] Norrrahim M.N.F., Ariffin H., Hassan M.A. et al.: International Journal of Nanotechnology 2019, 16 (11-12), 668. http://dx.doi.org/10.1504/IJNT.2019.107360

[10] Rani M.S.A., Ahmad A., Mohamed N.S.: Ionics 2018, 24 (3), 807.

https://doi.org/10.1007/s11581-017-2235-2

[11] Cintil J.C., Lovely M., Sabu T.: Reviews on Advanced Materials Science 2014, 37, 20.

[12] Rani M.S.A., Mohammad M., Sua'it M.S. et al.: Polymer Bulletin 2020. https://doi.org/10.1007/s00289-020-03382-2

[13] Tapia-Blácido D.R., Maniglia B.C., Martelli-Tosi M., Passos V.F.: "Biopackaging" (Ed. Masuelli M.A.), CRC Press, 2017, p.192.

[14] Tan B.K., Ching Y.C., Poh S.C. et al.: Polymers 2015, 7 (11), 2205. https://doi.org/10.3390/polym7111509

[15] Najiha Badar S., Mohammad M., Emdadi Z., Yaakob Z.: Biofuels 2018. https://doi.org/10.1080/17597269.2018.1472978

[16] Nuruddin M., Chowdhury A., Haque S.A. et al.: Cellulose Chemistry and Technology 2011, 45 (5-6), 347.

[17] Zuin V.G., Ramin L.Z.: "Chemistry and Chemical Technologies in Waste Valorization" 2018, pp. 229282.

[18] Mishra R.K., Sabu A., Tiwari S.K.: Journal of Saudi Chemical Society 2018, 22, 949. https://doi.org/10.1016/j.jscs.2018.02.005

[19] "The Synthetic Strategies for Unique Properties in Cellulose Nanocrystal Materials". http://repository.lib.ncsu.edu/ir/bitstream 
[20] Hubbe M.A., Rojas O.J., Lucia L.A., Sain M.: BioResources 2008, 3 (3), 929.

[21] Norrrahim M.N.F., Ariffin H., Yasim-Anuar T.A.T. et al:: IOP Conference Series: Materials Science and Engineering 2018, 368, 012034. https://doi.org/10.1088/1757-899X/368/1/012034

[22] Moon R.J.M., Martini A., Nairn J. et al.: Chemical Society Reviews 2011, 40, 3941. http://dx.doi.org/10.1039/c0cs00108b

[23] Clasen C., Kulicke W.M.: Progress in Polymer Science 2001, 26 (9), 1839. http://dx.doi.org/10.1016/S0079-6700(01)00024-7

[24] Varshney V.K., Naithani S.: "Cellulose fibers: Bio-and nano-polymer composites" (Eds. Kalia S., Kaith B.S., Kaur I.), Springer-Verlag, Berlin Heidelberg 2011, pp. 43-60. http://dx.doi.org/10.1007/978-3-642-17370-7

[25] Börjesson M., Westman G.: “Cellulose-Fundamental Aspects and Current Trends", INTECH, 2015, pp. 159-191. https://doi.org/10.5772/61899

[26] Norrrahim M.N.F., Ariffin H., Yasim-Anuar T.A.T. et al.: Cellulose 2018, 25 (7), 3853. https://doi.org/10.1007/s10570-018-1859-3

[27] Kumar A., Negi Y.S., Choudhary V., Bhardwaj N.K.: Journal of Materials Physics and Chemistry 2014, 2 (1), 1. http://dx.doi.org/10.12691/jmpc-2-1-1

[28] Dos Santos R.M., Neto W.P.F., Silvério H.A. et al.: Industrial Crops and Products 2013, 50, 707.

[29] Wulandari W.T., Rochliadi A., Arcana I.M.: IOP Conference Series: Materials Science and Engineering 2016, 107, 012045. https://doi.org/10.1088/1757-899X/107/1/012045

[30] Lani N.S., Ngadi N., Johari A., Jusoh M.: Journal of Nanomaterials 2014, 2014, ID 702538. https://doi.org/10.1155/2014/702538

[31] Kampeerapappun P.: Journal of Metals, Materials and Minerals 2015, 25 (1), 19. http://dx.doi.org/10.14456/jmmm.2015.3

[32] Hornsby P., Mohamad M., McMullan C. et al.: "Nanocellulose reinforced polymers derived from banana tree and other fibre sources", ECCM15-15 ${ }^{\text {th }}$ European Conference on Composite Materials, Venice, Italy, 24-28 June 2012.

[33] Zhang X., Han G., Jiang W. et al.: BioResources 2016, 11 (3), 6590.

http://dx.doi.org/10.15376/biores.11.3.6590-6599

[34] Chen W., Yu H., Liu Y. et al.: Cellulose 2011, 18 (2), 433. http://dx.doi.org/10.1007/s10570-011-9497-z

[35] Saelee K., Yingkamhaeng N., Nimchua T., Sukyai P.: Proceedings of The 26th Annual Meeting of the Thai Society for Biotechnology and International Conference, Mae Fah Lunag University (School of Science) 2014, pp. 26-29.

[36] Jonoobi M., Oladi R., Davoudpour Y. et al.: Cellulose 2015, 22 (2), 935.

http://dx.doi.org/10.1007/s10570-015-0551-0
[37] Nasution, H. and Sitompul, S.: IOP Conference Series: Materials Science and Engineering 2017, 180 (1), 012007.

[38] Purkait B.S., Ray D., Sengupta S. et al.: Industrial \& Engineering Chemistry Research 2011, 50 (2), 871. https://doi.org/10.1021/ie101797d

[39] Zain M., Fazelin N., Yusop M., Ahmad I.: Nutrition \& Food Sciences 2016, 5 (1), 1.

[40] Klemm D., Kramer F., Moritz S. et al.: Angewandte Chemie International Edition 2011, 50, 5438. http://dx.doi.org/10.1002/anie.201001273

[41] Gardner D.J., Oporto G.S., Mills R., Samir M.A.S.A.: Journal of Adhesion Science and Technology 2008, 22 (5-6), 545. https://doi.org/10.1163/156856108X295509

[42] Johansson C., Bras J., Mondragon I. et al.: BioResources 2012, 7 (2), 2506. http://dx.doi.org/10.15376/biores.7.2.2506-2552

[43] Mashkour M., Rahimnejad M., Mashkour M., Soavi F.: Journal of Power Sources 2020, 478, 228822. https://doi.org/10.1016/j.jpowsour.2020.228822

[44] Wegner T.H.: “Cellulose Nanomaterials: The Sustainable Material of Choice for the 21st Century 2012", Energy Efficiency and Renewable Energy, Sustainable Nanomaterials Workshop.

[45] Deepa B., Abraham E., Cherian B.M. et al.: Bioresource Technology 2011, 102 (2), 1988.

http://www.scopus.com/inward/record.url?e$\mathrm{id}=2$-s2.0-78650710292\& partnerID=40\&md5=ca3ad939fb6bd5634dfec2dfe38209c9

[46] Chen Y.W., Lee H.V., Abd Hamid S.B.: BioResources 2016, 11 (2), 4645.

[47] Zawawi D., Mohd Z., Angzzas S., Ashuvila M.A.: Journal of Applied Sciences 2014, 14 (12), 1355. http://dx.doi.org/10.3923/jas.2014.1355.1358

[48] Rani M.S.A., Ahmad A., Mohamed N.S.: Polymer Bulletin 2018, 75 (11), 5061. https://doi.org/10.1007/s00289-018-2320-3

[49] Ishola M.M., Millati R., Syamsiah S. et al:: Molecules 2012, 17 (12), 14995.

https://doi.org/10.3390/molecules171214995

[50] She W.J., Burke L., Neimyer R. et al.: "Proceedings of the Conference on Design and Semantics of Form and Movement - Sense and Sensitivity, DeSForM 2017".

http://dx.doi.org/10.5772/intechopen.71109

[51] Lee K.Y., Aitomäki Y., Berglund L.A. et al.: Composites Science and Technology 2014, 105, 15.

https://doi.org/10.1016/j.compscitech.2014.08.032

[52] Kalia S., Kaith B.S., Kaur I.: Polymer Engineering \& Science 2009, 49 (7), 1253. https://doi.org/10.1002/pen.21328

[53] Einchhorn S.J., Dufresne A., Aranguren M.M. et al.: Journal of Materials Science 2010, 45, 1. http://dx.doi.org/10.1007/s10853-009-3874-0

[54] Habibi Y., Goffin A.L., Schiltz N. et al.: Journal of Materials Chemistry 2008, 18 (41), 5002. https://doi.org/10.1039/B809212E 
[55] Petersson L., Kvien I., Oksman K.: Composites Science and Technology 2007, 67 (11-12), 2535. http://dx.doi.org/10.1016/j.compscitech.2006.12.012

[56] Zoppe J.O., Peresin M.S., Habibi Y. et al.: ACS Applied Materials \& Interfaces 2009, 1 (9), 1996. https://doi.org/10.1021/am9003705

[57] Bondeson D., Oksman K.: Composite Interfaces 2007, 14 $(7-9), 617$. https://doi.org/10.1163/156855407782106519

[58] Kvien I., Tanem B.S., Oksman K.: Biomacromolecules 2005, 6 (6), 3160. http://dx.doi.org/10.1021/bm050479t

[59] Dufresne A.: "Monomers, Polymers and Composites from Renewable Resources" (Eds. Belgacem M.N., Gandini A.), Elsevier 2008, Chapter 19, pp. 401-418. https://doi.org/10.1016/B978-0-08-045316-3.00019-3

[60] Helbert W., Cavaille J.Y., Dufresne A.: Polymer Composites 1996, 17 (4), 604. https://doi.org/10.1002/pc.10650

[61] Alemdar A., Sain M.: Composites Science and Technology 2008, 68 (2), 557. https://doi.org/10.1016/j.compscitech.2007.05.044

[62] Elazzouzi-Hafraoui S., Nishiyama Y., Putaux J.L. et al.: Biomacromolecules 2008, 9 (1), 57. http://dx.doi.org/10.1021/bm700769p

[63] Khattab M.M., Abdel-Hady N.A., Dahman Y.: "Cellulose-Reinforced Nanofibre Composites, Production, Properties and Applications", Woodhead Publishing Series in Composites Science and Engineering 2017, pp. 483-516. https://doi.org/10.1016/B978-0-08-100957-4.00021-8

[64] Dong X.M., Kimura T., Revol J.F., Gray D.G.: Langmuir 1996, 12 (8), 2076. https://doi.org/10.1021/la950133b

[65] Morán J.I., Alvarez V.A., Cyras V.P., Vázquez A.: Cellulose 2008, 15 (1), 149. https://doi.org/10.1007/s10570-007-9145-9

[66] Araki J., Wada M., Kuga S.: Langmuir 2001, 17 (1), 21. http://dx.doi.org/10.1021/la001070m

[67] Bhatnagar A., Sain M.: Journal of Reinforced Plastics and Composites 2005, 24 (12), 1259. http://dx.doi.org/10.1177/0731684405049864
[68] Paralikar S.A., Simonsen J., Lombardi J.: Journal of Membrane Science 2008, 320 (1), 248. http://dx.doi.org/10.1016/j.memsci.2008.04.009

[69] Mangalam A.P., Simonsen J., Benight A.S.: Biomacromolecules 2009, 10 (3), 497. https://doi.org/10.1021/bm800925x

[70] Azizi Samir M.A.S., Alloin F., Sanchez J.Y. et al.: Macromolecules 2004, 37 (4), 1386. http://dx.doi.org/10.1021/ma030532a

[71] Morandi G., Heath L., Thielemans W.: Langmuir 2009, 25 (14), 8280. https://doi.org/10.1021/la900452a

[72] Bondeson D., Mathew A., Oksman K.: Cellulose 2006, 13 (2), 171.

https://doi.org/10.1007/s10570-006-9061-4

[73] Filson P.B., Dawson-Andoh B.E.: Bioresource Technology 2009, 100 (7), 2259. https://doi.org/10.1016/j.biortech.2008.09.062

[74] Lavoine N., Desloges I., Dufresne A., Bras J.: Carbohydrate Polymers 2012, 90 (2), 735. https://doi.org/10.1016/j.carbpol.2012.05.026

[75] Eichhorn S.J.: Soft Matter 2011, 7 (2), 303. https://doi.org/10.1039/C0SM00142B

[76] Wang Y., Cao X., Zhang L.: Macromolecular Bioscience 2006, 6 (7), 524. https://doi.org/10.1002/mabi.200600034

[77] Salehudin M.H., Saleh E., Muhamad I.I., Mamat S.N.H.: International Conference on Agricultural and Food Engineering for Life (Cafei 2012), 26-28 November 2012, Putrajaya, Malaysia.

[78] Long L.Y., Weng Y.X., Wang Y.Z.: Polymers 2018, 10 (6), 623. https://doi.org/10.3390/polym10060623

[79] Truong D.H., Dam M.S., Bujna E. et al.: Fuel 2021, 285, 119259. https://doi.org/10.1016/j.fuel.2020.119259

[80] Lin N., Dufresne A.: European Polymer Journal 2014, $59,302$. https://doi.org/10.1016/j.eurpolymj.2014.07.025

[81] Wang S., Lu A., Zhang L.: Progress in Polymer Science 2016, 53, 169. https://doi.org/10.1016/j.progpolymsci.2015.07.003

Received 12 X 2020.

\section{(2) Polimery - czasopismo naukowo-techniczne $\quad$ D Plik É Edycja Widok Historia zaskładki N Narzędzia PomoG \\ S) http://ichp.vot.pl/ g- Google 7 (ABD -

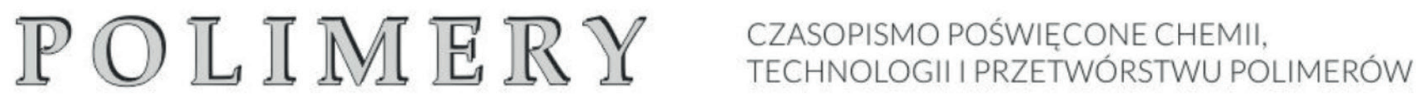

